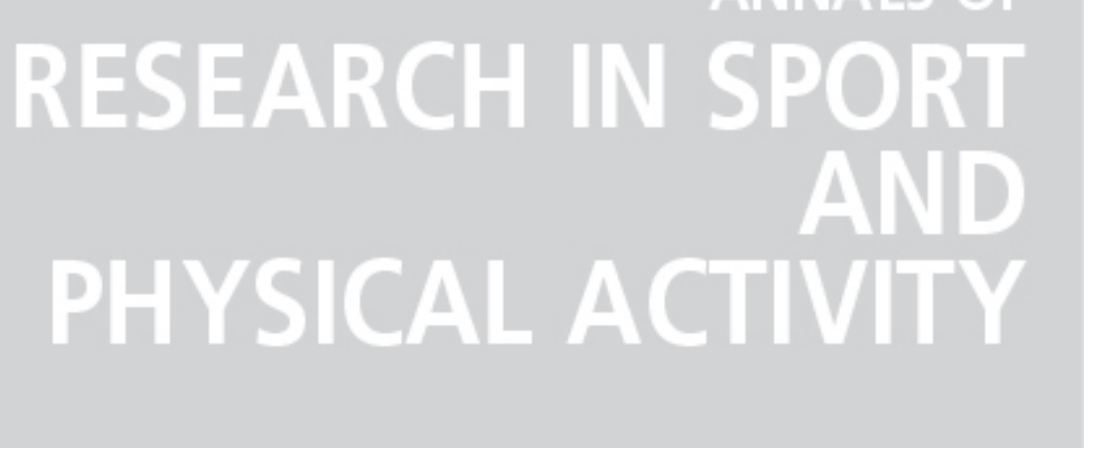

Effects of lifelong training on T lymphocytes senescence

Autor(es): $\quad$ Teixeira, Ana Maria; Minuzzi, Luciele G.

Publicado por: Imprensa da Universidade de Coimbra

URL

persistente: URI:http://hdl.handle.net/10316.2/44078

DOI: DOI:https://doi.org/10.14195/2182-7087_ex2018_15

Accessed : $\quad$ 26-Apr-2023 15:16:31

A navegação consulta e descarregamento dos títulos inseridos nas Bibliotecas Digitais UC Digitalis, UC Pombalina e UC Impactum, pressupõem a aceitação plena e sem reservas dos Termos e Condições de Uso destas Bibliotecas Digitais, disponíveis em https://digitalis.uc.pt/pt-pt/termos.

Conforme exposto nos referidos Termos e Condições de Uso, o descarregamento de títulos de acesso restrito requer uma licença válida de autorização devendo o utilizador aceder ao(s) documento(s) a partir de um endereço de IP da instituição detentora da supramencionada licença.

Ao utilizador é apenas permitido o descarregamento para uso pessoal, pelo que o emprego do(s) título(s) descarregado(s) para outro fim, designadamente comercial, carece de autorização do respetivo autor ou editor da obra.

Na medida em que todas as obras da UC Digitalis se encontram protegidas pelo Código do Direito de Autor e Direitos Conexos e demais legislação aplicável, toda a cópia, parcial ou total, deste documento, nos casos em que é legalmente admitida, deverá conter ou fazer-se acompanhar por este aviso. 


\section{ANNALS OF RESEARCH IN SPORT AND PHYSICAL ACTIVITY}




\title{
EFFECTS OF LIFELONG TRAINING ON T LYMPHOCYTES SENESCENCE
}

\author{
Ana Maria Teixeira ${ }^{1}$ and Luciele G. Minuzzi ${ }^{1}$
}

KEY WORDS: immunosenescence, masters athletes, inflammation

Aging has profound impact on the immune system, mainly on T-cells. The characteristics of immunosenescence from $T$ cell pool, include poor vaccination responses and an inverted CD4:CD8 ratio, low numbers and proportions of naive T-cells (that would impair the capacity of the immune system to deal with new pathogens), larger numbers of effector memory T-cells in late stage of differentiation. Also, persistent infections, such as cytomegalovirus (CMV), would further reduce the naïve T-lymphocyte repertoire and drive effector T- cells into senescence ${ }^{(1)}$. These senescent T-cells are apoptose resistant, incapable of dividing and thought to be the major cause of the chronic low-grade inflammation seen with age ${ }^{(2)}$. Older persons with more pronounced chronic low-grade inflammatory profile are more prone to frailty and mortality ${ }^{(3)}$. Furthermore, age-related loss of Treg function would contribute to a greater risk of autoimmune disease while the age-related increase in Treg numbers could result in compromised immune responses, increasing the risk of malignancies and infections. A recent model proposed that regular bouts of exercise can trigger preventive and/or restorative mechanisms of T-cell immunosenescence by inducing the apoptosis of senescent and functionally exhausted late stage differentiated T-cells and thus preventing overcrowding of the immune space ${ }^{(4,5)}$ which increases infection susceptibility to novel pathogens. Physical exercise preferentially mobilizes senescent T cells from the peripheral tissues into the blood, which might facilitate their subsequent apoptosis and create \"vacant spacel" for newly functional T cells to occupy and expand the nalu00efve T-cell repertoire.", "author" : [ \{ "dropping-particle" : "", "family" : "Simpson", "given" : "Richard J", "nondropping-particle" : "", "parse-names" : false, "suffix" : "" \} ], "container-title" : "Exercise and sport sciences reviews", "id" : "ITEM-1", "issue" : "1", "issued" : \{ "date-parts" : [ [ "2011", "1"] ] \}, "page" : "23-33", "title" : "Aging, persistent viral infections, and im-

\footnotetext{
1 Research Center for Sport and Physical Activity, Faculty of Sports Science and Physical Education, University of Coimbra, Portugal.
} 
munosenescence: can exercise \"make spacel"?", "type" : "article-journal", "volume" : "39" \}, "uris" : [ "http://www.mendeley.com/documents/?uuid=7d444808-8a79-407b9737-e7c3d971d57a" ] \}, \{ "id" : "ITEM-2", "itemData" : \{ "DOI" : "10.1159/000270905", "ISBN" : "1423-0003 (Electronic. Briefly, a 3 stage process is proposed: firstly, T-cells in a late differentiated stage are mobilized into the peripheral blood during exercise; Then, these cells leave the bloodstream to peripheral and/or inflamed tissues 1-2 $\mathrm{h}$ after exercise and a portion of these senescent $T$ cells subsequently undergo apoptosis, thus creating vacant space; Consequently, lowered T-cell numbers drive the positive feedback loop, increasing naive T-cell output, filling the vacant space and contributing to an expanded naive T-cell repertoire. Repetitions of this process in response to exercise would reduce the frequency of senescent $T$ cells over time, lowering infection risk and increasing healthy longevity. Master athletes represent an interesting sub-demographic group to test this theory since they maintain a high training load and frequency throughout life, and represent an "exceptionally successful aging" process. The aim of this study was to evaluate the effects of lifelong training on senescent $T$ lymphocytes and their response to acute exercise.

\section{MATERIAL AND METHODS}

Nineteen master athletes (53.5 \pm 8.94 yrs.) who regularly participated in training and competitions for more than 20 years and a control group of 9 healthy individuals $(53.7 \pm$ 6.04 yrs.) participated in this study. All subjects performed a progressive test to exhaustion on a cycle ergometer. Blood samples were obtained before (Pre), $10 \mathrm{~min}$ after the test (Post) and $1 \mathrm{~h}$ after the test (1h). Phenotypic study of peripheral blood T-cells was performed by flow cytometry. Expression of genes of interest was done on T-cells purified by cell sorting. Group comparisons were assessed using the Mann-Whitney $U$ test. Alpha level was set at 0.05 . For the analyses of change, accounting for the multilevel design of the study (level 1 units (intra-individual) within each level 2 unit (individuals of different groups)), hierarchical random effects models (REM) were constructed using a multilevel modeling approach.

\section{RESULTS}

$\mathrm{VO}_{2 \max }$ was higher for master athletes when compared to the control group $(P<0.001)$. No differences were founded for $\mathrm{CD}^{+}$and $\mathrm{CD} 8^{+} \mathrm{T}$-cells and their subsets between master athletes and the control group at all times of measurement. Also, total $\mathrm{CD}^{+}{ }^{+}, \mathrm{CD}^{+}$and $\mathrm{CD}^{+}{ }^{+} \mathrm{T}$-cells percentages did not increase with exercise. There were no significant differences in the proportion of Tregs either within the total lymphocyte population or within 
the CD4 T-cell population, between the two groups at baseline. There was no significant effect of acute exercise on the proportion (\%) of Tregs within total lymphocytes and CD4+ T-cells. However, acute exercise induced a significant increase in the number of Tregs at Post and returned to pre-exercise values at $1 \mathrm{~h}$ post for both groups. FoxP3, TGF- $\beta$ and IL10 mRNA expression was similar for both groups. For FoxP3 and TGF- $\beta$ after exercise the number of detected cases was different between groups, with higher results for master athletes $(P<0.05)$. IL-10 mRNA expression remained unchanged at all times of measurement for masters (Pre $=61.1 \%$; Post $=66.7 \%$ and $1 \mathrm{~h}$ Post $=50 \%$ of all subjects), while in the control group there was a tendency for fewer cases expressing mRNA for IL-10 (Pre $=22.2 \%$; Post $=55.6 \%$ and $1 \mathrm{~h}=22.2 \%$ ). Senescent $C D 4^{+}$and $C D 8^{+}$T-cells were higher in the control group when compared to masters before and $1 \mathrm{~h}$ after exercise. At baseline, masters had significant less percentage of senescent T lymphocytes $(-6.7829 \pm 3.06 \%), C D^{+}$ T-cells $(-5.8145 \pm 2.42)$ and $C D 4+$ senescent naive $(-5.3182 \pm 2.5761)$ and effector memory $(-4.3505 \pm 1.93 \%)$ T-cells. Regarding the CD8 ${ }^{+} \mathrm{T}$-cells, masters had significant less senescent CD8 ${ }^{+} T$-cells $(-13.0661 \pm 4.95)$, senescent $T C D 8^{+}$naive $(-9.3624 \pm 2.09)$, central memory $(-7.0282 \pm 3.065)$ and effector memory $(-12.0034 \pm 5.49)$ cells. No significant effect of sports participation (controls vs masters) was noted for the \% of senescent CD45RA expressing effector memory cells (EMRA) $C D 4^{+}$and $C D 8^{+} T$-cells. Senescent $C D 4^{+} \mathrm{T}$-cells were mobilized by exercise only in the masters and returned to Pre-values in $1 \mathrm{~h}$. Senescent CD8 $8^{+}$T-cells, $\mathrm{CM}$ and $\mathrm{EM} \mathrm{CD8}{ }^{+}$T-cells were also mobilized by exercise in the masters. These values return to Pre-values in $1 \mathrm{~h}$ after the end of the protocol. In the control group, only the senescent CD8 ${ }^{+}$CM T-cells increased at Post and their values remained elevated $1 \mathrm{~h}$ after the test. The senescent EMRA CD8 ${ }^{+}$T-cells did not increase at Post but decreased in $1 \mathrm{~h}$ to values below those observed at Pre and Post, in the masters. Age had a negative effect on the naive $\mathrm{CD}^{+} \mathrm{T}$-cells. $\mathrm{VO}_{2 \max }$ associated negatively with the percentage of total lymphocytes and positively with the proportion of naive CD4 ${ }^{+} \mathrm{T}$-cells. The mRNA expression of the CCR7 gene for naive $C D 8^{+} T$-cells and the Fas- $L$ gene for effector-terminal $C D 8^{+} T$-cells was not different between masters and controls and did not change in response to the maximal protocol test.

\section{CONCLUSION}

Master athletes have elevated anti-inflammatory markers and maintain the number and markers of activation of regulatory $T$ cells as adaptive responses to exercise. Lifelong training decreased the percentage of senescent naive, $C M$ and EM CD8 ${ }^{+}$T-cells and senescent naive and $\mathrm{CM} \mathrm{CD} 4^{+} \mathrm{T}$-cells. In both $\mathrm{CD} 4^{+}$and $\mathrm{CD} 8^{+}$T-cell subsets, the percentage of senescent EMRA T cells was also lower in the master athletes. Maintaining high levels of aerobic fitness during the natural course of aging may help prevent the accumulation of senescent 
T-cells and the maintenance of function and number of T regs, hallmarks of a younger immune system.

\section{REFERENCES}

1. Turner, J.E. (2016). "Is immunosenescence influenced by our lifetime "dose" of exercise?", Biogerontology, Vol. $17^{(3)}$, pp. 581-602.

2. Van Deursen, J.M. (2014), "The role of senescent cells in ageing" Nature, Vol. 509 pp. 439-446.

3. Krabbe, K.S., Pedersen, M., Bruunsgaard, H. (2004), "Inflammatory mediators in the elderly", Experimental Gerontology, Vol. 39, pp. 687-699.

4. Simpson, R.J., (2011), "Aging, persistent viral infections, and immunosenescence: can exercise "make space"?" Exercise and sport sciences reviews, 39"1), pp.23-33.

5. Simpson, R.J. \& Guy, K., (2010), "Coupling aging immunity with a sedentary lifestyle: has the damage already been done?--a mini-review" Gerontology, 56(5), pp.449-458 